\title{
ЕФЕКТИВНІСТЬ КІНЕЗІОТЕРАПІЇ В РЕАБІЛІТАЦІЇ ПАЦІЕНТІВ 3 УСВІДОМЛЕНОЮ РУХОВОЮ АКТИВНІСТЮ ПІСЛЯ ТЯЖКОЇ ЧЕРЕПНО-МОЗКОВОЇ ТРАВМИ
}

\section{О.В. Кулик}

Науково-практичний центр нейрореабілітації "Нодус", м. Бровари

Ключові слова:
постравматичний
коматозний стан,
кінезіотерапія,
кінезіологічне
обстеження,
рухова
активність.
Клінічна та
експериментальна
патологія Т.18, №1
(67). С.65-73.
DOI:10.24061/1727-
4338.XVIII.1.67.2019.208
E-mail: a.kulyk@
nodus.ua

nodus.ua
Мета роботи - вивчення ефективності кінезіотерапї в реабілітації пацієнтів 3 усвідомленою руховою активністю після тяжкої черепно-мозкової травми.

Матеріали і методи. Досліджено 220 пачієнтів з посттравматичними посткоматозними станами після перенесеної тяжкої черепно-мозкової травми (ЧМТ). Кінезіологічні обстеження (КО) проведені у 100\% $(N=220)$ хворих на всіх етапах відновлення свідомості. КО містило: лінійне вимірювання довжини та окружності кінцівок; вимір об'єму пасивних рухів у суглобах; кінезіологічне тестування загальної рухової активності за індексом Мотрісайті; тестування здатності долати нав'язаний опір та опір до дії зовнішньої сили; координаторні тести, інструментальне дослідження координації рухів, локомоторно-координаторне тестування на комп'ютеризованому комплексі з Б33 Balance Trainer ${ }^{\circledR}$ (Medica medizintechnik Gmbh, Німеччина), при кутових відхиленнях 6 та 12 градусів $i$ регулюванням жорсткості від 3 до 7 та вертикалізачійній платформі зі зворотнім нахилом СН-38.03.10 (Україна) і поточним градуюванням кута нахилу, асочійованої з пульсоксиметром; інструментальне тестування складних рухових актів, рівень функиіональних можливостей в системах закритого та відкритого кінематичного ичклу. Статистичну обробку отриманих даних проводили з використанням пакета прикладних програм "Statistica 6", пакета комп'ютерного аналізу "Office Excel 2016", вибіркового методу: вибіркової середньої, похибки середньої; для визначення вірогідності різниці між групами - непараметричні методи: критерій $\chi^{2}$ для порівняння якісних показників та т-критерій для порівняння кількісних параметрів; для порівняння двох незалежних груп використовували метод Манна-Уїтні.

Результати. За даними проведеного КО пацієнтів виявилося, щзо реабілітаційний потенціал визначався руховими (фізичними) можливостями пацієнта на конкретній стадії відновлення свідомості. За результатами тестування визначена чітка динаміка позитивного виконання загально-координаторних тестів у більшості хворих залежно від просування на вищі стадії відновлення свідомості. Встановлено, щзо загальна оиінка рухової активності у вигляді індекса Мотрісайті в динаміці зростала. Встановлено кореляційний прямий зв'язок $(r<0,54)$ прогнозу переходу на вищу стадію посткоматозного порушення свідомості з динамікою відновлення "тонких" кінезіологічних характеристик статусу пацієнта.

Висновки. Використання кінезіотерапії в індивідуальних реабілітаційних програмах у пацієнтів після тяжкої черепно-мозкової травми, визначило достеменний приріст м'язової сили, фізичної активності та покращення загального стану, охоплюючи зростання інтелектуально-мнестичних процесів з реалізацією їх в найближчому оточенні.

\section{Ключевые слова: постравматическое коматозное состояние, кинезиотерапия, кинезиологичесое исследование, двигательная активность.}

Клиническая и экспериментальная патология Т.18, №1 (67). C.65-73.

\section{ЭФФЕКТИВНОСТЬ КИНЕЗОТЕРАПИИ В РЕАБИЛИТАЦИИ ПАЦИЕНТОВ С ОСОЗНАННОЙ ДВИГАТЕЛЬНОЙ АКТИВНОСТЬЮ ПОСЛЕ ТЯЖЕЛОЙ ЧЕРЕПНО- МОЗГОВОЙ ТРАВМЫ}

\section{А.В. Кулик}

Цель работы - изучение эффективности кинезотерапии в реабилитации пацичентов с осознанной двигательной активностью после тяжелой черепно-мозговой травмы. Материалы и методы. Обследовано 220 пациентов с посттравматическими посткоматозными состояниями после перенесенной тяжелой ЧМТ. Кинезиологические исследования (КИ) проведены у 100\% (N=220) больных на всех этапах восстановления сознания. КИ включили в себя: линейное измерение длины и окружности конечностей; измерение объёма пассивных движений в суставах; кинезиологическое тестирование общей двигательной активности по индексу Мотрисайти; тестирование способности преодолевать навязанное сопротивление и сопротивление к действию внешней силы; координационные тесты, инструментальные исследования координации движений, локомоторно-координационное тестирование на компью- 
теризированном комплексе с БОС Balance Treiner ${ }^{\circledR}$ (Medica medizintechnik Gmbh, Германия), при угловых отклонениях 6 и 12 градусов и регулированием жёсткости от 3 до 7, вертикализационной платформы с обратным наклоном СН-38.03.10 (Украина) и текущим градуированием угла наклона, ассоциированной с пульсоксиметром; инструментальное тестирование сложных двигательных актов, уровень функциональных возможностей в системах закрытого и открытого кинематического ичикла. Статистическую обработку полученных данных проводили с использованием пакета компьютерного анализа "Office Excel 2016", выборочного метода: выборочной средней, погрешности средней; для определения вероятности разнииь между группами - непараметрические методы: критерий $\chi^{2}$ дя сравнения качественных показателей и t-критерий для сравнения количественных параметров; для сравнения двух независимых групп использовали метод Манна-Уитни.

Результаты. По данным проведенного КИ пациентов выявлено, что реабилитациионный потенциал определялся двигательными (физическими) возможностями пациента на конкретной стадии восстановления сознания. Согласно результатов тестирования определена четкая динамика положительного выполнения обще-координационных тестов у большинства больных в зависимости от продвижения на высшие стадии восстановления сознания. Установлено, что общая оиенка двигательной активности в виде Индекса Монтрисайти в динамике возросла. Установлено корреляционную прямую связь $(r<0,54)$ прогноза перехода на высшую стадию посткоматозного нарушения сознания с динамикой возобновления "тонких" кинезиологических характеристик статуса пациентов.

Выводы. Использование кинезиотерапии в индивидуальных реабилитационных программах у пациентов после тяжелой ЧМТ определило достоверныи прирост мышечной силь, физической активности и улучшения общего состояния, включая прирост интеллектуально-мнестических процессов с реализацией их в ближайшем окружении.

\section{THE EFFECTIVENESS OF KINESIOTHERAPY IN THE REHABILITATION OF PATIENTS WITH CONSCIOUS MOTOR ACTIVITY AFTER SEVERE TRAUMATIC BRAIN INJURY}

\section{o.V. Kulik}

Objective - study of the kinesiotherapy effectiveness in the rehabilitation of patients with conscious motor activity after severe traumatic brain injury.

Material and methods. 220 patients with post-traumatic post-coma conditions after severe traumatic brain injury were studied. Kinesiological examinations (KE) were performed in $100 \%(N=220)$ of patients with post-traumatic post-coma conditions at all stages of consciousness recovery. KE included: linear measurement of the length and circumference of limbs; measurement of the volume of passive movements in joints; kinesiological testing of general motor activity evaluated with the Motricity Index; testing the ability to overcome imposed resistance and resistance to the action of external force; coordination tests, instrumental study of motor coordination, locomotor coordination testing on a computerized complex with BFB Balance Treiner ${ }^{\circledR}$ (Medica medizintechnik Gmbh, Germany) with angular deviations of 6 and 12 degrees and stiffness adjustment from 3 to 7 and a verticalization platform with a reverse inclination $\mathrm{CH}-38.03 .10$ (Ukraine) and the current gradient of the tilt angle associated with a pulse oximeter; instrumental testing of complex motor acts, the level of functionality in systems of closed and open kinematic cycle. Statistical processing of the data was performed using the software package "Statistica 6", the computer analysis package "Office Excel 2016", the sampling method: the sample mean, the error of the mean; to determine the reliability of differences between groups - non-parametric methods: $\chi^{2}$ criterion for the comparison of qualitative indicators and t-criterion for the comparison of quantitative parameters; the Mann-Whitney test was used for the comparison of two independent groups,.

Results. According to the data of the KE of patients, it turned out that the rehabilitation potential was determined by the motor (physical) capabilities of the patient at a specific stage of recovery of consciousness. According to the test results, a clear dynamic of positive performance of general coordination tests was determined for the majority of patients, depending on progress to higher stage of consciousness recovery. It was revealed that the overall assessment of motor activity in the form of the Motrisight Index increased in dynamics. A direct correlation was revealed $(r<0.54)$ in the forecast of transition to the highest stage of post-coma impairment of consciousness with the dynamics of restoring 
the "thin" kinesiological characteristics of the patient's status.

Conclusions. The use of kinesiotherapy in individual rehabilitation programs for patients after severe traumatic brain injury determined a reliable increase in muscle strength, physical activity and improvement of the general condition, including the growth of intellectual and mental processes with their implementation in the immediate surroundings.

\section{Вступ}

Травматичне ураження головного мозку є важливою проблемою клінічної медицини, що має не тільки медичну, але й соціальну значущість [1]. Внаслідок зростання кількості військових конфліктів у світі та розвитку військових технологій спостерігається тенденція до зростання кількості черепно-мозкових травм (ЧМТ). Удосконалення підходів до лікування цих травм дало змогу збільшити рівень виживання хворих, проте внаслідок цього зросла і медико-соціальна значимість удосконалення системи лікування віддалених їх наслідків, що внаслідок значного рівня неврологічних, когнітивних та адаптаційних порушень, мають значний негативний вплив на якість життя хворих та їх оточення [2].

Відновлення рухової активності пацієнтів, що перенесли тяжку черепно-мозкову травму, є одним із пріоритетних завдань реабілітаційного лікування [3].

Під час проведення реабілітаційного лікування здійснюється оцінка функціонального стану пацієнта та обираються відповідні методи індивідуальної програми реабілітації [4], тому підбір методик кінезіотерапії хворих $з$ посттравматичними посткоматозними станами після перенесеної тяжкої ЧМТ є важливим завданням і підтверджує актуальність нашого дослідження.

\section{Мета роботи}

Вивчення ефективності кінезіотерапії у реабілітації пацієнтів з усвідомленою руховою активністю після тяжкої черепно-мозкової травми.

\section{Матеріали та методи дослідження}

У дослідженні брали участь 220 пацієнтів 3 посттравматичними посткоматозними станами після перенесеної тяжкої ЧМТ, що проходили реабілітаційне лікування в ТОВ "Науково-практичний центр нейрореабілітації "Нодус". Клінічно для хворих було характерно залежно від стадій наступні види відновлення свідомості: синдром реінтеграції свідомості, перехідні синдроми, синдром ясної свідомості. У програмах реабілітації були застосовані такі методики кінезіотерапії: пасивна розробка кінцівок, ерготерапія, тренування у комп'ютеризованому комплексі з біологічно-зворотнім зв'язком (Б33) Balance Trainer, лікувальна гімнастика, механотерапія з використанням апарата Мотомед, нейро-активаційні тренування з підвісними системами REDCORD (Норвегія).

Кінезіологічні обстеження (КО) проведені у $100 \%$ $(\mathrm{N}=220)$ хворих з посттравматичними посткоматозними станами на усіх етапах відновлення свідомості. КО містило: лінійне вимірювання довжини та окружності кінцівок; вимір об'єму пасивних рухів в суглобах; кінезіологічне тестування загальної рухової активності за індексом Мотрісайті; лінійне вимірювання довжини та

Клінічна та експериментальна патологія. 2019. Т.18, №1 (67) окружності кінцівок; тестування здатності долати нав'язаний опір та опір дії зовнішньої сили; координаторні тести, інструментальне дослідження координації рухів, локомоторно-координаторне тестування на комп'ютеризованому комплексі з Б33 Balance Trainer ${ }^{\circledR}$ (Medica medizintechnik Gmbh, Німеччина) при кутових відхиленнях 6 та 12 градусів і регулюванням жорсткості від 3 до 7 та вертикалізаційній платформі зі зворотнім нахилом CH-38.03.10 (Україна) і поточним градуванням кута нахилу, асоційованої з пульсоксиметром; інструментальне тестування складних рухових актів, рівень функціональних можливостей у системах закритого та відкритого кінематичного циклу [5-15].

Проводили Статистичну обробку отриманих даних з використанням пакета прикладних програм "Statistica 6", пакета комп'ютерного аналізу "Office Excel 2016", вибіркового методу: вибіркової середньої, похибки середньої; для визначення вірогідності різниці між групами - непараметричні методи: критерій $\chi^{2}$ для порівняння якісних показників та t-критерій для порівняння кількісних параметрів; для порівняння двох незалежних груп використовували метод Манна-Уїтні.

\section{Результати та їх обговорення}

За даними проведеного КО пацієнтів виявилено, що реабілітаційний потенціал визначався руховими (фізичними) можливостями пацієнта на конкретній стадії відновлення свідомості.

Зокрема, визначено, що в динаміці відновлення свідомості після тривалої коми, починаючи з стадії сплутаної свідомості з аспонтанністю, більшість досліджуваних кінезіологічних показників істотно покращуються (табл. 1).

Однак для всіх пацієнтів притаманний дефіцит об'єму активних рухів у паретичних кінцівках до $75 \%$, та збереження виразних паретичних змін. Важливе клінічне значення в оцінці результатів реабілітаційного лікування має динаміка рухових порушень, що досліджувалась відповідно до індексу Мотрісайті у пацієнтів на 6А-8 стадіях відновлення свідомості табл. 2).

Згідно $з$ даними табл. 2 встановлено, що загальна оцінка рухової активності у вигляді Індекса Мотрісайті в динаміці зростала. Причому в паретичних кінцівках 3 силою м'язів $<3$ балів приріст рухової активності і мав значно меншу виразність, проте в стадіях 6А-8 володів тим же експоненціальним характером $\left(\mathrm{f}_{\mathrm{x}}=2^{\mathrm{x}}\right)$, що і в паретичних кінцівках з силою м'язів $\geq 3$ балів/и.

Одним з важливих завдань індивідуальної реабілітаційної програми пацієнта після перенесеної ЧМТ є відновлення та корекція рухового стереотипу, показники загальної координації у пацієнтів, сила м'язів яких складала не менше 3 бали, наведені в табл. 3.

За результатами тестування, визначена чітка динаISSN 1727-4338 https://ww.bsmu.edu.ua 
Таблиця 1

Динаміка кінезіологічних показників у паціснтів залежно від стадії посткоматозного порушення свідомості

\begin{tabular}{|c|c|c|c|c|c|c|}
\hline \multirow{2}{*}{ Кінезіологічні показники } & \multicolumn{6}{|c|}{$\begin{array}{l}\text { Стадія посткоматозного порушення свідомості за Доброхотовою Т.А. } \\
\text { Кількість хворих, що дійшли до даної стадії протягом часу дослідження }\end{array}$} \\
\hline & $\begin{array}{l}6 \mathrm{~A}-\mathrm{C} \Pi \mathrm{C}_{3} \mathrm{~A} \\
\quad(\mathrm{~N}=138)\end{array}$ & $\begin{array}{l}6 \mathrm{5}-\mathrm{MPCC} \\
(\mathrm{N}=112)\end{array}$ & $\begin{array}{l}6 \mathrm{~B}-\mathrm{ACC} \\
(\mathrm{N}=93)\end{array}$ & $\begin{array}{l}7 \mathrm{~A}-Д \mathrm{C} \\
(\mathrm{N}=72)\end{array}$ & $\begin{array}{l}7 \mathrm{~B}-\mathrm{KC} \\
(\mathrm{N}=56)\end{array}$ & $\begin{array}{c}8-9 C_{3} \\
\mathrm{KEP} \\
(\mathrm{N}=46)\end{array}$ \\
\hline $\begin{array}{l}\text { Довжина кінцівок, в } \\
\text { динаміці }\end{array}$ & попередня & попередня & попередня & попередня & попередня & попередня \\
\hline $\begin{array}{l}\text { Окружність кінцівок, } \\
\text { лінійна, в динаміці середній } \\
\text { \%, ранговий показник зміни } \\
\Delta \text { i }\end{array}$ & $\begin{array}{l}\text { попередня } \\
\text { (поп.) }\end{array}$ & $\begin{array}{l}\text { попередня } \\
\text { (поп.) }\end{array}$ & $\begin{array}{c}\text { ч-3 } \uparrow \text { м'яз-ї } \\
\text { маси } \uparrow \text { на } \\
6,1-8,2 \% \text { поп. }\end{array}$ & $\begin{array}{l}\text { ч-з } \uparrow \text { м'яз-ї } \\
\text { маси } \uparrow \text { на } \\
9,4-12,7 \% \\
\text { поп. } \\
\end{array}$ & $\begin{array}{l}\text { ч-з } \uparrow \text { м'яз- } \\
\text { ї маси } \uparrow \\
\text { на } 6,8- \\
8,8 \% \text { поп. }\end{array}$ & $\begin{array}{l}\text { ч-з } \uparrow \text { м'яз-ї } \\
\text { маси } \uparrow \text { на } \\
8,1-10,5 \% \\
\text { поп. } \\
\end{array}$ \\
\hline $\begin{array}{l}\text { Об'єм (об.) активних рухів в } \\
\text { основних суглобах } \\
\text { паретичних кінцівок-3 силою } \\
\text { м'язів } \geq 3 \text { балів, середнє } \\
\text { значення }\end{array}$ & $\begin{array}{l}\text { у 44,92\% досяг } \\
\text { повн. фіз. об. }\end{array}$ & $\begin{array}{l}\text { у } 58,03 \% \text { досяг } \\
\text { повн. фіз. об. }\end{array}$ & $\begin{array}{c}\text { у } 81,72 \% \\
\text { досяг повн. } \\
\text { фіз. об. }\end{array}$ & $\begin{array}{c}\text { у } 87,5 \% \\
\text { досяг повн. } \\
\text { фіз. об. }\end{array}$ & $\begin{array}{c}\text { у } 91,07 \% \\
\text { досяг } \\
\text { повн. фіз. } \\
\text { об. }\end{array}$ & $\begin{array}{c}\text { у } 100 \% \\
\text { досяг } \\
\text { повн. фіз. } \\
\text { об. }\end{array}$ \\
\hline $\begin{array}{l}\text { Об'єм (об.) активних рухів в } \\
\text { основних суглобах } \\
\text { паретичних кінцівок, з силою } \\
\text { м'язів <3 балів, середнє } \\
\text { значення за ( L.McPeak, 1996; } \\
\text { М. Вейс, 1986)*** }\end{array}$ & $\begin{array}{c}\text { дефіцит > 75\% } \\
\text { фіз.об'єму у } \\
100 \% \text { вип. }\end{array}$ & $\begin{array}{c}\text { дефіцит }>75 \% \\
\text { фіз. об'єму у } \\
\text { 100\% випадках }\end{array}$ & $\begin{array}{c}\text { дефіцит > } \\
75 \% \text { фіз. } \\
\text { об'єму у } \\
100 \% \\
\text { випадках }\end{array}$ & $\begin{array}{c}\text { дефіцит > } \\
75 \% \\
\text { фіз.об'єму у } \\
100 \% \\
\text { випадках }\end{array}$ & $\begin{array}{c}\text { дефіцит > } \\
75 \% \text { фіз. } \\
\text { об'єму у } \\
100 \% \\
\text { випадках }\end{array}$ & $\begin{array}{c}\text { дефіцит > } \\
75 \% \text { фіз. } \\
\text { об'єму у } \\
100 \% \\
\text { випадках }\end{array}$ \\
\hline $\begin{array}{l}\text { Об'єм (об.) пасивних рухів в } \\
\text { основних суглобах } \\
\text { паретичних кінцівок, } 3 \text { силою } \\
\text { м'язів } \geq 3 \text { балів, середнє } \\
\text { значення }\end{array}$ & $\begin{array}{l}\text { у } 81,15 \% \text { досяг } \\
\text { повн. фіз. об. }\end{array}$ & $\begin{array}{l}\text { у 90,17\% досяг } \\
\text { повн. фіз. об. }\end{array}$ & $\begin{array}{c}\text { у 94,62\% } \\
\text { досяг повн. } \\
\text { фіз. об. }\end{array}$ & $\begin{array}{l}\text { у } 100 \% \text { досяг } \\
\text { повн. фіз. об. }\end{array}$ & $\begin{array}{c}\text { у } 100 \% \\
\text { досяг } \\
\text { повн. фіз. } \\
\text { об. }\end{array}$ & $\begin{array}{c}\text { у } 100 \% \\
\text { досяг } \\
\text { повн. фіз. } \\
\text { об. }\end{array}$ \\
\hline $\begin{array}{l}\text { Об'єм (об.)пасивних рухів в } \\
\text { основних суглобах } \\
\text { паретичних кінцівок з силою } \\
\text { м'язів <3 балів, середнє } \\
\text { значення за ( L.McPeak, 1996; } \\
\text { М. Вейс, 1986)*** }\end{array}$ & $\begin{array}{c}\text { дефіцит > 50\% } \\
\text { фіз.об'єму у } \\
100 \% \text { вип. }\end{array}$ & $\begin{array}{c}\text { дефіцит > 50\% } \\
\text { фіз.об'єму у } \\
100 \% \text { вип. }\end{array}$ & $\begin{array}{c}\text { дефіцит > } \\
50 \% \\
\text { фіз.об'єму у } \\
100 \% \text { вип. }\end{array}$ & $\begin{array}{c}\text { дефіцит > } \\
50 \% \\
\text { фiз.об'єму у } \\
84,72 \% \text { вип. }\end{array}$ & $\begin{array}{l}\text { дефіцит > } \\
50 \% \\
\text { фiз.об'єму } \\
\text { у } 71,42 \% \\
\text { вип. }\end{array}$ & $\begin{array}{l}\text { дефіцит > } \\
50 \% \\
\text { фіз.об'єму } \\
\text { у } 67,39 \% \\
\text { вип. }\end{array}$ \\
\hline $\begin{array}{l}\text { Тестування } \\
\text { антигравітаційного руху } 3 \\
\text { ізометричним скороченням в } \\
\text { піковій точці (ПТ) } \\
\text { антигравітаційної дуги; }\end{array}$ & $\begin{array}{c}\text { у } 44,71 \% \\
\text { віднов. повн. } \\
\text { фіз. об. } \\
\text { антиграв. рухів, } \\
\text { утрим. } 1 \text { хв в } \\
\text { ПТ }\end{array}$ & $\begin{array}{c}\text { у 57,6\% віднов. } \\
\text { повн. фіз. об. } \\
\text { антиграв. рухів, } \\
\text { утрим. } 1 \text { хв в } \\
\text { ПТ }\end{array}$ & $\begin{array}{c}\text { у } 81,42 \% \\
\text { віднов. повн. } \\
\text { фіз. об. } \\
\text { антиграв. } \\
\text { рухів, утрим. } \\
1 \text { хв в ПТ }\end{array}$ & $\begin{array}{c}\text { у } 88,33 \% \\
\text { віднов. повн. } \\
\text { фіз. об. } \\
\text { антиграв. } \\
\text { рухів, утрим. } \\
2 \text { хв в ПТ }\end{array}$ & $\begin{array}{l}\text { у } 89,36 \% \\
\text { віднов. } \\
\text { повн. фіз. } \\
\text { об. } \\
\text { антиграв. } \\
\text { рухів, } \\
\text { утрим. } 2 \\
\text { хв в ПТ }\end{array}$ & $\begin{array}{c}\text { у } 100 \% \\
\text { віднов. } \\
\text { повн. фіз. } \\
\text { об. } \\
\text { антиграв. } \\
\text { рухів, } \\
\text { утрим. } 3 \\
\text { хв в ПТ }\end{array}$ \\
\hline $\begin{array}{l}\text { Тестування здатності долати } \\
\text { нав'язаний опір (оп.) та опір } \\
\text { до дії зовнішньої сили в } \\
\text { паретичних кінцівках } 3 \\
\text { силою м'язів } \geq 3 \text { балів (що } \\
\text { дорівнює силі маси (m) такої } \\
\text { кінцівки ). }\end{array}$ & $\begin{array}{l}\text { у } 22,46 \% \text { здат. } \\
\text { дол. такий оп. }\end{array}$ & $\begin{array}{l}\text { у } 36,6 \% \text { здат. } \\
\text { дол. такий оп. }\end{array}$ & $\begin{array}{l}\text { у } 56,98 \% \\
\text { здат. дол. } \\
\text { такий оп. }\end{array}$ & $\begin{array}{l}\text { у } 56,94 \% \\
\text { здат. дол. } \\
\text { такий оп.+ } \\
\text { викор. } \\
\text { пар.кінц., як } \\
\text { оп. для } \\
\text { хотьби }\end{array}$ & $\begin{array}{c}\text { у } 85,71 \% \\
\text { здат. дол. } \\
\text { такий } \\
\text { оп.+ } \\
\text { викор. } \\
\text { пар.кінц., } \\
\text { як оп. для } \\
\text { хотьби }\end{array}$ & $\begin{array}{c}\text { у } 100 \% \\
\text { здат. дол. } \\
\text { такий оп.+ } \\
\text { викор. } \\
\text { пар.кінц., } \\
\text { як оп. для } \\
\text { хотьби }\end{array}$ \\
\hline \multicolumn{7}{|c|}{ Пояснення використаних скорочень : } \\
\hline $\begin{array}{r}\text { Сплутаність свідомості } 3 \\
\text { аспонтанністю - }\end{array}$ & $6 A-C \Pi C C_{3} A$ & повного - & повн. & \multicolumn{2}{|c|}{ утримували - } & утрим. \\
\hline $\begin{array}{r}\text { Мовнорухова сплутаність } \\
\text { свідомості - }\end{array}$ & $65-M P C C$ & $\begin{array}{r}\text { фізіологічного } \\
-\end{array}$ & фіз. & \multicolumn{2}{|c|}{ відновився - } & віднов. \\
\hline $\begin{array}{r}\text { Амнестична сплутаність } \\
\text { свідомості - }\end{array}$ & $6 B-A C C$ & через - & $4-3$ & \multicolumn{2}{|c|}{ антигравітаційний - } & антиграв. \\
\hline Дисмнестичний синдром - & 7А-ДС & м'язової - & м'яз-ї & \multicolumn{2}{|r|}{ кінцівки - } & кіни. \\
\hline Корсаковський синдром - & $7 Б-K C$ & випадків - & Bun. & \multicolumn{2}{|r|}{ здатність - } & здат. \\
\hline Синдром ясної свідомості - & $8-Я C$ з $K E P$ & долали - & дол. & \multicolumn{2}{|c|}{ паретичної - } & nap. \\
\hline
\end{tabular}

міка позитивного виконання загальнокоординаторних тестів у більшості хворих залежно від просування на вищі стадії відновлення свідомості. Однак, слід зауважити, що дрібні (швидкісно залежні) загальнокоординаторні акти відновилися лише у пацієнтів в 8-й стадії посткоматозного порушення свідомості. Така динаміка притаманна й для середньо швидкісних локомоторно-координаторних рухів, краще виконання яких характерне саме для пацієнтів на вищих стадіях відновлення свідомості.

Клінічна та експериментальна патологія. 2019. Т.18, №1 (67) 
Таблиця 2

Зведені показники оцінки рухової активності за індексом Мотрісайті у пацієнтів залежно від стадії посткоматозного порушення свідомості

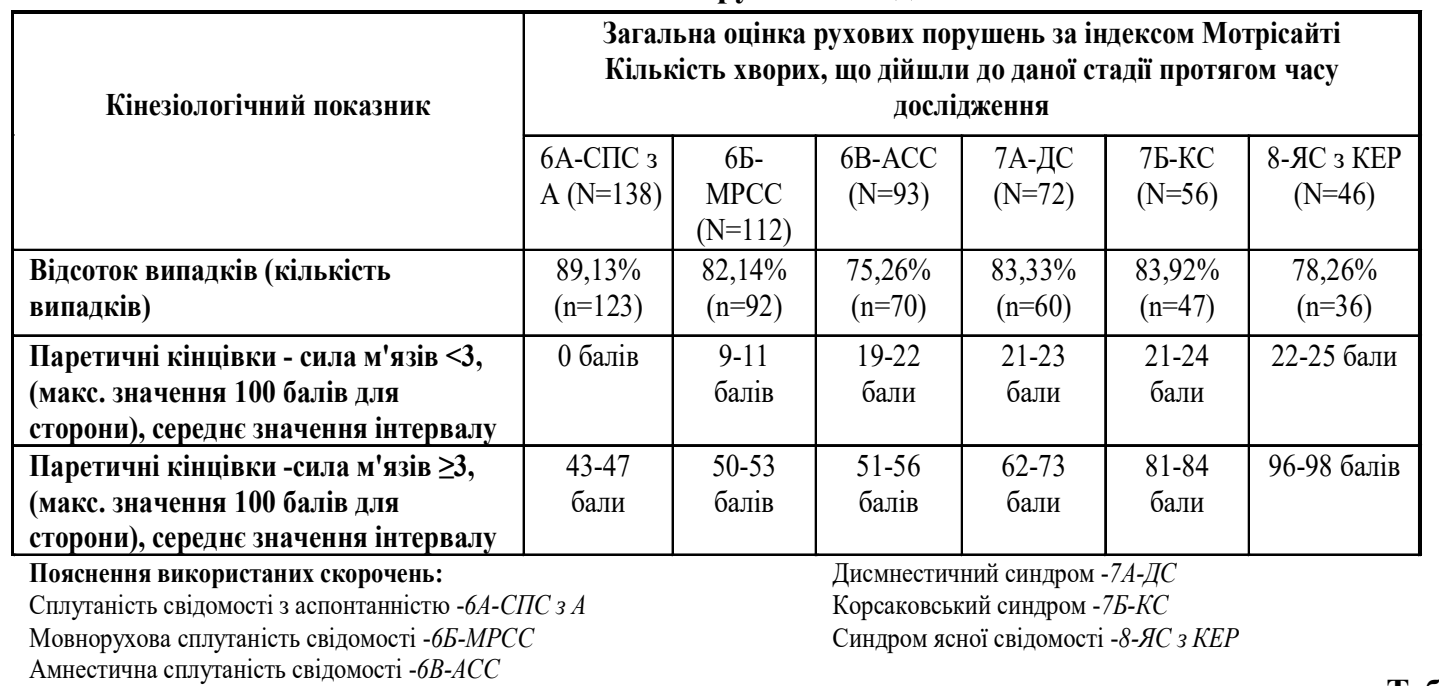

Таблиця 3

Динаміка результатів тестування локомоторної координації у паціснтів, залежно від стадії посткоматозного порушення свідомості

\begin{tabular}{|c|c|c|c|c|c|c|}
\hline \multirow{2}{*}{$\begin{array}{l}\text { Кінезіологічний } \\
\text { показник }\end{array}$} & \multicolumn{6}{|c|}{$\begin{array}{c}\text { Динаміка результатів тестування загальної координації } \\
\text { у паціснтів з силою м'язів } \geq 3 \text { балів } \\
\text { Кількість хворих, що дійшли до даної стадії протягом часу дослідження }\end{array}$} \\
\hline & $\begin{array}{c}\text { 6А-CПС } 3 \text { A } \\
\quad(\mathrm{N}=138)\end{array}$ & $\begin{array}{c}6 \mathrm{~B}-\mathrm{MPCC} \\
(\mathrm{N}=112)\end{array}$ & $\begin{array}{c}6 \mathrm{~B}-\mathrm{ACC} \\
(\mathrm{N}=93)\end{array}$ & $\begin{array}{l}7 \mathrm{~A}-Д С \\
(\mathrm{~N}=72)\end{array}$ & $\begin{array}{l}7 \mathrm{~b}-\mathrm{KC} \\
(\mathrm{N}=56)\end{array}$ & $\begin{array}{c}\text { 8-ЯС } 3 \text { KEP } \\
\quad(\mathrm{N}=46)\end{array}$ \\
\hline $\begin{array}{l}\text { Відсоток випадків } \\
\text { (кількість випадків) }\end{array}$ & $\begin{array}{l}89,13 \% \\
(n=123)\end{array}$ & $\begin{array}{c}82,14 \% \\
(n=92)\end{array}$ & $\begin{array}{l}75,26 \% \\
(n=70)\end{array}$ & $\begin{array}{l}83,33 \% \\
(n=60)\end{array}$ & $\begin{array}{l}83,92 \% \\
(n=47)\end{array}$ & $\begin{array}{c}78,26 \% \\
(n=46)\end{array}$ \\
\hline $\begin{array}{l}\text { Кількість обстежених } \\
\text { хворих на даній стадії, } \\
\text { що мали силу м'язів } 3 \\
\text { бали і вище } \\
\end{array}$ & $\begin{array}{c}44,71 \% \\
(\mathrm{n}=55 ; \mathrm{N}=123)\end{array}$ & $\begin{array}{c}57,6 \% \\
(\mathrm{n}=53 ; \mathrm{N}=92)\end{array}$ & $\begin{array}{c}81,42 \% \\
(\mathrm{n}=57 ; \mathrm{N}=70)\end{array}$ & $\begin{array}{c}88,33 \% \\
(\mathrm{n}=53 ; \mathrm{N}=60)\end{array}$ & $\begin{array}{c}89,36 \% \\
(\mathrm{n}=42 ; \mathrm{N}=47)\end{array}$ & $\begin{array}{c}100 \% \\
(n=46 ; N=46)\end{array}$ \\
\hline $\begin{array}{l}\text { Тест: без допомоги } \\
\text { поворот } 3 \text { живота на } \\
\text { спину }\end{array}$ & $\begin{array}{c}43,63 \% \\
(\mathrm{n}=24 ; \mathrm{N}=55) \\
\text { виконали тест }\end{array}$ & $\begin{array}{c}49,05 \% \\
(\mathrm{n}=26 ; \mathrm{N}=53) \\
\text { виконали тест }\end{array}$ & $\begin{array}{c}45,61 \% \\
(\mathrm{n}=26 ; \mathrm{N}=57) \\
\text { виконали тест }\end{array}$ & $\begin{array}{c}60,37 \% \\
(\mathrm{n}=32 ; \mathrm{N}=53) \\
\text { виконали тест }\end{array}$ & $\begin{array}{c}80,95 \% \\
(\mathrm{n}=34 ; \mathrm{N}=42) \\
\text { виконали тест }\end{array}$ & $\begin{array}{c}100 \% \\
(\mathrm{n}=46 ; \mathrm{N}=46) \\
\text { виконали тест }\end{array}$ \\
\hline $\begin{array}{l}\text { Тест: без допомоги } \\
\text { поворот } 3 \text { спини на } \\
\text { живіт }\end{array}$ & $\begin{array}{c}49,09 \% \\
(\mathrm{n}=27 ; \mathrm{N}=55) \\
\text { виконали тест }\end{array}$ & $\begin{array}{c}50,94 \% \\
(\mathrm{n}=27 ; \mathrm{N}=53) \\
\text { виконали тест }\end{array}$ & $\begin{array}{c}50,87 \% \\
(\mathrm{n}=29 ; \mathrm{N}=57) \\
\text { виконали тест }\end{array}$ & $\begin{array}{c}62,26 \% \\
(\mathrm{n}=33 ; \mathrm{N}=53) \\
\text { виконали тест }\end{array}$ & $\begin{array}{c}78,57 \% \\
(\mathrm{n}=33 ; \mathrm{N}=42) \\
\text { виконали тест }\end{array}$ & $\begin{array}{c}100 \% \\
(\mathrm{n}=46 ; \mathrm{N}=46) \\
\text { виконали тест }\end{array}$ \\
\hline $\begin{array}{l}\text { Тест: колінно- } \\
\text { п'яткова проба в } \\
\text { положенні сидячи }\end{array}$ & $\begin{array}{c}43,63 \% \\
(\mathrm{n}=24 ; \mathrm{N}=55) \\
\text { виконали тест }\end{array}$ & $\begin{array}{c}50,94 \% \\
(\mathrm{n}=27 ; \mathrm{N}=53) \\
\text { виконали тест }\end{array}$ & $\begin{array}{c}49,12 \% \\
(\mathrm{n}=28 ; \mathrm{N}=57) \\
\text { виконали тест }\end{array}$ & $\begin{array}{c}52,83 \% \\
(\mathrm{n}=28 ; \mathrm{N}=53) \\
\text { виконали тест }\end{array}$ & $\begin{array}{c}80,95 \% \\
(\mathrm{n}=34 ; \mathrm{N}=42) \\
\text { виконали тест }\end{array}$ & $\begin{array}{c}91,3 \% \\
(\mathrm{n}=42 ; \mathrm{N}=46) \\
\text { виконали тест }\end{array}$ \\
\hline $\begin{array}{l}\text { Тест: колінно- } \\
\text { п'яткова проба в } \\
\text { положенні лежачи }\end{array}$ & $\begin{array}{l}41,81 \% \\
(\mathrm{n}=23 ; \mathrm{N}=55) \\
\text { виконали тест }\end{array}$ & $\begin{array}{c}45,28 \% \\
(\mathrm{n}=24 ; \mathrm{N}=53) \\
\text { виконали тест }\end{array}$ & $\begin{array}{c}52,63 \% \\
(\mathrm{n}=30 ; \mathrm{N}=57) \\
\text { виконали тест }\end{array}$ & $\begin{array}{c}58,49 \% \\
(\mathrm{n}=31 ; \mathrm{N}=53) \\
\text { виконали тест }\end{array}$ & $\begin{array}{c}83,33 \% \\
(\mathrm{n}=35 ; \mathrm{N}=42) \\
\text { виконали тест }\end{array}$ & $\begin{array}{c}89,13 \% \\
(\mathrm{n}=41 ; \mathrm{N}=46) \\
\text { виконали тест }\end{array}$ \\
\hline $\begin{array}{l}\text { Тест: кілочки, за } 18 \\
\text { сек: } 2 \text { сек/кілочок ( } 9 \\
\text { кілочків) }\end{array}$ & $\begin{array}{c}0 \% \\
(\mathrm{n}=0 ; \mathrm{N}=55) \\
\text { виконали тест }\end{array}$ & $\begin{array}{c}0 \% \\
(\mathrm{n}=0 ; \mathrm{N}=53) \\
\text { виконали тест }\end{array}$ & $\begin{array}{c}0 \% \\
(\mathrm{n}=0 ; \mathrm{N}=57) \\
\text { виконали тест }\end{array}$ & $\begin{array}{c}0 \% \\
(\mathrm{n}=0 ; \mathrm{N}=53) \\
\text { виконали тест }\end{array}$ & $\begin{array}{c}2,38 \% \\
(\mathrm{n}=1 ; \mathrm{N}=42) \\
\text { виконали тест }\end{array}$ & $\begin{array}{c}19,56 \% \\
(\mathrm{n}=9 ; \mathrm{N}=46) \\
\text { виконали тест }\end{array}$ \\
\hline $\begin{array}{l}\text { Тест: прийняти } \\
\text { положення сидячи } 3 \\
\text { положення лежачи }\end{array}$ & $\begin{array}{l}56,36 \% \\
(\mathrm{n}=31 ; \mathrm{N}=55) \\
\text { виконали тест }\end{array}$ & $\begin{array}{c}58,49 \% \\
(\mathrm{n}=31 ; \mathrm{N}=53) \\
\text { виконали тест }\end{array}$ & $\begin{array}{c}54,38 \% \\
(\mathrm{n}=31 ; \mathrm{N}=57) \\
\text { виконали тест }\end{array}$ & $\begin{array}{c}64,15 \% \\
(\mathrm{n}=34 ; \mathrm{N}=53) \\
\text { виконали тест }\end{array}$ & $\begin{array}{c}85,71 \% \\
(\mathrm{n}=36 ; \mathrm{N}=42) \\
\text { виконали тест }\end{array}$ & $\begin{array}{c}100 \% \\
(\mathrm{n}=36 ; \mathrm{N}=36) \\
\text { виконали тест }\end{array}$ \\
\hline $\begin{array}{l}\text { Тест: сидіння без } \\
\text { підтримки протягом } \\
5 \text { хв }\end{array}$ & $\begin{array}{c}60 \% \\
(\mathrm{n}=33 ; \mathrm{N}=55) \\
\text { виконали тест }\end{array}$ & $\begin{array}{c}62,26 \% \\
(\mathrm{n}=33 ; \mathrm{N}=53) \\
\text { виконали тест }\end{array}$ & $\begin{array}{c}59,64 \% \\
(\mathrm{n}=34 ; \mathrm{N}=57) \\
\text { виконали тест }\end{array}$ & $\begin{array}{c}64,15 \% \\
(\mathrm{n}=34 ; \mathrm{N}=53) \\
\text { виконали тест }\end{array}$ & $\begin{array}{c}85,71 \% \\
(\mathrm{n}=36 ; \mathrm{N}=42) \\
\text { виконали тест }\end{array}$ & $\begin{array}{c}100 \% \\
(\mathrm{n}=46 ; \mathrm{N}=46) \\
\text { виконали тест }\end{array}$ \\
\hline $\begin{array}{l}\text { Тест: піднімання та } \\
\text { опускання } 3 \\
\text { положення сидячи }\end{array}$ & $\begin{array}{l}69,09 \% \\
(\mathrm{n}=38 ; \mathrm{N}=55) \\
\text { виконали тест } \\
\end{array}$ & $\begin{array}{c}71,69 \% \\
(\mathrm{n}=38 ; \mathrm{N}=53) \\
\text { виконали тест }\end{array}$ & $\begin{array}{c}68,42 \% \\
(\mathrm{n}=39 ; \mathrm{N}=57) \\
\text { виконали тест }\end{array}$ & $\begin{array}{c}75,47 \% \\
(\mathrm{n}=40 ; \mathrm{N}=53) \\
\text { виконали тест }\end{array}$ & $\begin{array}{c}92,85 \% \\
(\mathrm{n}=39 ; \mathrm{N}=42) \\
\text { виконали тест }\end{array}$ & $\begin{array}{c}100 \% \\
(\mathrm{n}=46 ; \mathrm{N}=46) \\
\text { виконали тест }\end{array}$ \\
\hline $\begin{array}{l}\text { Пояснення використан } \\
\text { Сплутаність свідомості } 3 \\
\text { Мовнорухова сплутаністі }\end{array}$ & 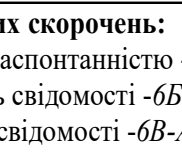 & $\begin{array}{l}6 A-C П C C_{3} A \\
\text { МРСC }\end{array}$ & $\begin{array}{l}\text { Дисмнестични } \\
\text { Корсаковськи } \\
\text { Синдром ясно }\end{array}$ & $\begin{array}{l}\text { й синдром -7A } \\
\text { й синдром -7Б- } \\
\text { i свідомості -8 }\end{array}$ & $\begin{array}{l}\text { ДC } \\
К С C \\
Я C_{3} K E P\end{array}$ & \\
\hline
\end{tabular}


Для оцінки ефективності використання кінезіотерапії у реабілітаційному лікуванні пацієнтів в динаміці проводили визначення локомоторно-координаторних функцій. Так, у всіх без винятку хворих, що перебували на 6-7 стадіях відновлення посткоматозного порушення свідомості, дослідження проводилися тільки з додатковою фіксацією в підвісах системи гравітаційного розвантаження Guldmann ${ }^{\circledR}$ (Нідерланди) за умови постійного інструментального моніторингу основних гемодинамічних та дихальних показників (артеріальний тиск, пульс, сатурація кисню) функцією коліноупору, мінімальних кутах жорсткості і 3 кутовим відхиленням 6 градусів. Пацієнти з синдромом ясної свідомості могли працювати без підтримки в підвісах, в середніх і максимальних рівнях жорсткості з кутовим відхиленням 12 градусів (наближене до фізіологічної норми), без коліноупору. Слід відзначити, що при досягненні стадії синдрому ясної свідомості залишалася частина хворих $(4,35 \%(n=2 ; \mathrm{N}=46))$, які продовжували незадовільно виконувати запропоновані локомоторно-координаторні тести "збір яблук", "рухи по лініях" і при куті відхилення 12 градусів, кількість цих хворих зросла до 15,22 \% $(\mathrm{n}=7 ; \mathrm{N}=46)$. (табл. 4.)

Зведені результати діагностики дефіциту сили (порівняння кінематичних зон правих/лівих верхніх та нижніх кінцівок), виявлення резерву компенсації сили

Таблиця 4

Зведені результати в динаміці тестування локомоторної координації у пацієнтів залежно від стадії посткоматозного порушення свідомості

\begin{tabular}{|c|c|c|c|c|c|c|}
\hline \multicolumn{7}{|c|}{$\begin{array}{r}\text { Діагностика локомоторно-координаторної активності на апарараті Balance Trainer® (Medica medizintechnik Gmbh, } \\
\text { Німеччина) та вертикалізаційній платформі зі зворотнім нахилом СН-38.03.10 (Україна) і поточним градуванням } \\
\text { кута нахилу, асоційованої з пульсоксиметром у паціснтів } 3 \text { силою м'язів } \geq 3 \text { балів }\end{array}$} \\
\hline \multirow{2}{*}{$\begin{array}{l}\text { Кінезіологічний показник, } \\
\text { Balanse-Soft 01.04.00/Medica } \\
\text { medizintechnik Gmbh }\end{array}$} & \multicolumn{6}{|c|}{$\begin{array}{l}\text { Динаміка результатів апаратного тестування локомоторної координації } \\
\text { Кількість хворих, що дійшли до даної стадії протягом часу дослідження }\end{array}$} \\
\hline & $\begin{array}{l}\text { 6А-СПС } 3 \text { A } \\
(\mathrm{N}=138)\end{array}$ & $\begin{array}{c}\text { 6Б-МРCC } \\
(\mathrm{N}=112)\end{array}$ & $\begin{array}{c}\text { 6B-ACC } \\
(\mathrm{N}=93)\end{array}$ & $\begin{array}{l}7 \mathrm{~A}-Д \mathrm{C} \\
(\mathrm{N}=72)\end{array}$ & $\begin{array}{l}7 \mathrm{5}-\mathrm{KC} \\
(\mathrm{N}=56)\end{array}$ & $\begin{array}{l}\text { 8-ЯC } 3 \text { KEP } \\
(\mathrm{N}=46)\end{array}$ \\
\hline $\begin{array}{l}\text { Відсоток обстежених випадків } \\
\text { (кількість ) }\end{array}$ & $\begin{array}{l}89,13 \% \\
(\mathrm{n}=123) \\
\end{array}$ & $\begin{array}{l}82,14 \% \\
(\mathrm{n}=92)\end{array}$ & $\begin{array}{l}75,26 \% \\
(\mathrm{n}=70)\end{array}$ & $\begin{array}{l}83,33 \% \\
(\mathrm{n}=60)\end{array}$ & $\begin{array}{l}100 \% \\
(n=56)\end{array}$ & $\begin{array}{c}100 \% \\
(\mathrm{n}=46) \\
\end{array}$ \\
\hline \multicolumn{7}{|c|}{ Кутове відхилення 6 градусів } \\
\hline $\begin{array}{l}\text { Задовільне виконання } \\
\text { локомоторно координаторних } \\
\text { тестів }\end{array}$ & $\begin{array}{c}26,02 \% \\
(\mathrm{n}=32 ; \mathrm{N}=123)\end{array}$ & $\begin{array}{c}38,04 \% \\
(\mathrm{n}=35 ; \mathrm{N}=92)\end{array}$ & $\begin{array}{c}52,86 \% \\
(n=37 ; N=70)\end{array}$ & $\begin{array}{c}63,33 \% \\
(\mathrm{n}=38 ; \mathrm{N}=60)\end{array}$ & $\begin{array}{c}91,05 \% \\
(n=41 ; N=56)\end{array}$ & $\begin{array}{c}95,65 \% \\
(n=44 ; N=46)\end{array}$ \\
\hline $\begin{array}{c}\text { Використання підвісів } \\
\text { Guldman }\end{array}$ & $\begin{array}{l}\begin{array}{l}91,05 \% \\
(\mathrm{n}=112) \\
\text { пост. викор. }\end{array} \\
\end{array}$ & $\begin{array}{l}94,56 \% \\
(\mathrm{n}=87) \\
\text { пост. викор. }\end{array}$ & $\begin{array}{l}90 \%(\mathrm{n}=63) \\
\text { пост. викор. }\end{array}$ & $\begin{array}{l}80 \%(\mathrm{n}=48) \\
\text { пост. викор. }\end{array}$ & $\begin{array}{c}57,14 \% \\
(\mathrm{n}=32) \\
\text { пост. викор. }\end{array}$ & $\begin{array}{c}36,96 \% \\
(\mathrm{n}=17) \\
\text { пост. викор. }\end{array}$ \\
\hline Використання коліноупору & $\begin{array}{c}\text { 91,05\% } \\
(\mathrm{n}=112) \\
\text { пост. викор. }\end{array}$ & $\begin{array}{c}94,56 \% \\
(\mathrm{n}=87) \\
\text { пост. викор. }\end{array}$ & $\begin{array}{l}90 \%(\mathrm{n}=63) \\
\text { пост. викор. }\end{array}$ & $\begin{array}{c}91,05 \% \\
(\mathrm{n}=46) \\
\text { пост. викор. }\end{array}$ & $\begin{array}{c}55,36 \% \\
(\mathrm{n}=31) \\
\text { пост. викор. }\end{array}$ & $\begin{array}{c}36,96 \% \\
(\mathrm{n}=17) \\
\text { пост. викор. }\end{array}$ \\
\hline Жорсткість пристрою & $\begin{array}{c}95,93 \% \\
(\mathrm{n}=118) \\
\text { мінім. }\end{array}$ & $\begin{array}{l}97,82 \% \\
(\mathrm{n}=90) \\
\text { мінім. }\end{array}$ & $\begin{array}{l}95,93 \% \\
(\mathrm{n}=58) \\
\text { мінім. }\end{array}$ & $\begin{array}{c}86,67 \% \\
(\mathrm{n}=52) \\
\text { мінім. }\end{array}$ & $\begin{array}{c}66,07 \% \\
(\mathrm{n}=37) \\
\text { мінім. }\end{array}$ & $\begin{array}{l}36,96 \% \\
(\mathrm{n}=17) \\
\text { мінім. }\end{array}$ \\
\hline Нестійкість гемодинаміки & 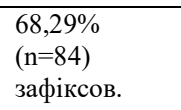 & $\begin{array}{c}91,11 \% \\
(\mathrm{n}=82) \\
\text { зафіксов. }\end{array}$ & $\begin{array}{c}72,86 \% \\
(\mathrm{n}=51) \\
\text { зафіксов. }\end{array}$ & $\begin{array}{c}68,33 \% \\
(\mathrm{n}=41) \\
\text { зафіксов. }\end{array}$ & $\begin{array}{c}37,5 \% \\
(\mathrm{n}=21) \\
\text { зафіксов. }\end{array}$ & $\begin{array}{c}19,57 \% \\
(\mathrm{n}=9) \\
\text { зафіксов. }\end{array}$ \\
\hline \multicolumn{7}{|c|}{ Кутове відхилення 12 градусів } \\
\hline $\begin{array}{c}\text { Задовільне виконання } \\
\text { локомоторно координаторних } \\
\text { тестів }\end{array}$ & $\begin{array}{c}15,45 \% \\
(\mathrm{n}=19 ; \mathrm{N}=123)\end{array}$ & $\begin{array}{c}22,83 \% \\
(\mathrm{n}=21 ; \mathrm{N}=92)\end{array}$ & $\begin{array}{c}31,43 \% \\
(\mathrm{n}=22 ; \mathrm{N}=70)\end{array}$ & $\begin{array}{c}41,67 \% \\
(n=25 ; N=60)\end{array}$ & $\begin{array}{c}57,14 \% \\
(\mathrm{n}=32 ; \mathrm{N}=56)\end{array}$ & $\begin{array}{c}84,78 \% \\
(n=39 ; N=46)\end{array}$ \\
\hline $\begin{array}{c}\text { Використання підвісів } \\
\text { Guldman }\end{array}$ & $\begin{array}{c}100 \% \\
(\mathrm{n}=123) \\
\text { пост. викор. }\end{array}$ & $\begin{array}{l}100 \%(\mathrm{n}=92) \\
\text { пост. викор. }\end{array}$ & $\begin{array}{c}100 \% \\
(\mathrm{n}=70) \\
\text { пост. викор. }\end{array}$ & $\begin{array}{c}96,67 \% \\
(\mathrm{n}=58) \\
\text { пост. викор. }\end{array}$ & $\begin{array}{c}71,43 \% \\
(\mathrm{n}=40) \\
\text { пост. викор. }\end{array}$ & $\begin{array}{c}36,96 \% \\
(\mathrm{n}=17) \\
\text { пост. викор. }\end{array}$ \\
\hline Використання коліноупору & $\begin{array}{c}100 \% \\
(\mathrm{n}=123) \\
\text { пост. викор. }\end{array}$ & $\begin{array}{l}100 \%(\mathrm{n}=92) \\
\text { пост. викор. }\end{array}$ & $\begin{array}{c}100 \% \\
(\mathrm{n}=70) \\
\text { пост. викор. }\end{array}$ & $\begin{array}{c}96,67 \% \\
(\mathrm{n}=58) \\
\text { пост. викор. }\end{array}$ & $\begin{array}{c}\text { 67,86\% } \\
(\mathrm{n}=38) \\
\text { пост. викор. }\end{array}$ & $\begin{array}{c}36,96 \% \\
(\mathrm{n}=17) \\
\text { пост. викор. }\end{array}$ \\
\hline Жорсткість пристрою & $\begin{array}{l}95,93 \% \\
(\mathrm{n}=118) \\
\text { мінім. }\end{array}$ & $\begin{array}{l}97,83 \% \\
(\mathrm{n}=90) \\
\text { мінім. }\end{array}$ & $\begin{array}{l}88,57 \% \\
(\mathrm{n}=62) \\
\text { мінім. }\end{array}$ & $\begin{array}{l}88,33 \% \\
(\mathrm{n}=53) \\
\text { мінім. }\end{array}$ & $\begin{array}{l}82,46 \% \\
(\mathrm{n}=47) \\
\text { мінім. }\end{array}$ & $\begin{array}{l}45,65 \% \\
(\mathrm{n}=21), \\
\text { мінім. }\end{array}$ \\
\hline Нестійкість гемодинаміки & $\begin{array}{c}72,36 \% \\
(\mathrm{n}=89) \\
\text { зафіксов. }\end{array}$ & $\begin{array}{c}91,3 \%(\mathrm{n}=84) \\
\text { зафіксов. }\end{array}$ & $\begin{array}{c}81,43 \% \\
(\mathrm{n}=57) \\
\text { зафіксов. }\end{array}$ & $\begin{array}{c}71,67 \% \\
(\mathrm{n}=43) \\
\text { зафіксов. }\end{array}$ & $\begin{array}{c}48,21 \% \\
(\mathrm{n}=27) \\
\text { зафіксов. }\end{array}$ & $\begin{array}{c}23,91 \% \\
(\mathrm{n}=11) \\
\text { зафіксов. }\end{array}$ \\
\hline
\end{tabular}

Пояснення використаних скорочень:

Сплутаність свідомості з аспонтанністю -6A-CПС 3 A Мовнорухова сплутаність свідомості - $65-M P C C$

Амнестична сплутаність свідомості - $6 B-A C C$

Дисмнестичний синдром -7А-ДС

Корсаковський синдром -7Б-КС

Синдром ясної свідомості -8-ЯС з КЕР постійно -пост.

використовували -викор

зафіксовано -зафіксов.

мінімальна -мінім. 
ослаблених м'язів, змін м'язового тонусу, оцінку перехідних варіантів спастики, особливо латентних пікових іiі варіантів, проводили на діагностично-лікувальному комплексі THERA-vital ${ }^{\circledR}$ (Medica Medizintechnik GmbH, Німеччина) у пасивній, напівпасивній рухових моделях подані на табл. 5

Відповідно до даних, зазначених в табл. 5, встановлено аналогічні закономірності динаміки кінезіологічних показників під час тестування функції кінцівок. Варто відзначити, що значна частина пацієнтів на стадіях з ви-

Таблиця 5

Зведені результати тестування функції кінцівок у паціснтів залежно від стадії посткоматозного порушення свідомості

\begin{tabular}{|c|c|c|c|c|c|c|}
\hline \multicolumn{7}{|c|}{$\begin{array}{c}\text { Діагностика дефіциту максимальної сили (порівняння кінематичних зон правих/лівих } \\
\text { виявлення резерву компенсації сили ослаблених м'язів, змін тонусу м'язів } 3 \text { силою } \\
\text { лікувальному комплексі } \\
\text { THERA-vital® (Medica Medizintechnik GmbH, Німеччина) }\end{array}$} \\
\hline \multirow{2}{*}{$\begin{array}{c}\text { Кінезіологічні показники, } \\
\text { Systeminfos CTRL } \\
\text { V5.7/TermA000-220:3.0.0. } \\
\text { Build0001 } \\
\text { Kernel Version:1.02 } \\
\text { PicoMOD } 4 \text { TheraTrainer }\end{array}$} & \multicolumn{6}{|c|}{$\begin{array}{l}\text { Динаміка результатів апаратного тестування функції кінцівок } \\
\text { Кількість хворих, що дійшли до даної стадії протягом часу дослідження }\end{array}$} \\
\hline & $\begin{array}{l}6 \mathrm{~A}-\mathrm{C} \Pi \mathrm{C}_{3} \mathrm{~A} \\
\quad(\mathrm{~N}=138)\end{array}$ & $\begin{array}{l}6 \mathrm{5}-\mathrm{MPCC} \\
(\mathrm{N}=112)\end{array}$ & $\begin{array}{l}6 \mathrm{~B}-\mathrm{ACC} \\
(\mathrm{N}=93)\end{array}$ & $\begin{array}{l}7 \mathrm{~A}-Д С \\
(\mathrm{~N}=72)\end{array}$ & $\begin{array}{l}7 \mathrm{~b}-\mathrm{KC} \\
(\mathrm{N}=56)\end{array}$ & $\begin{array}{l}\text { 8-ЯC } 3 \text { КEP } \\
\quad(\mathrm{N}=46)\end{array}$ \\
\hline $\begin{array}{l}\text { Відсоток обстежених } \\
\text { випадків (кількість ) }\end{array}$ & $\begin{array}{l}68,12 \% \\
(n=94)\end{array}$ & $73,21 \%(n=82)$ & $\begin{array}{l}79,57 \% \\
(n=74)\end{array}$ & $\begin{array}{l}77,78 \% \\
(n=56)\end{array}$ & $\begin{array}{l}83,93 \% \\
(n=47)\end{array}$ & $\begin{array}{l}100 \% \\
(n=46)\end{array}$ \\
\hline Потужність > 45 Ватт & $\begin{array}{c}\text { лише } 34,04 \% \\
(\mathrm{n}=32) \\
\text { досягнули }\end{array}$ & $\begin{array}{c}\text { лише } 43,9 \% \\
(\mathrm{n}=36) \\
\text { досягнули }\end{array}$ & $\begin{array}{c}\text { лише } 51,35 \% \\
(\mathrm{n}=38) \\
\text { досягнули }\end{array}$ & $\begin{array}{c}\text { лише } \\
66,07 \% \\
(\mathrm{n}=37) \\
\text { досягнули }\end{array}$ & $\begin{array}{c}\text { лише } \\
78,72 \% \\
(\mathrm{n}=37) \\
\text { досягнули }\end{array}$ & $\begin{array}{c}\text { лише } \\
82,61 \% \\
(\mathrm{n}=38) \\
\text { досягнули }\end{array}$ \\
\hline $\begin{array}{l}\text { Швидкість обертів > } \\
\pm 40 / 1 \text { хв. }\end{array}$ & $\begin{array}{c}\text { лише } 36,17 \% \\
(\mathrm{n}=34) \\
\text { досягнули }\end{array}$ & $\begin{array}{c}\text { лише } 42,68 \% \\
(\mathrm{n}=35) \\
\text { досягнули }\end{array}$ & $\begin{array}{c}\text { лише } 52,7 \% \\
(\mathrm{n}=39) \\
\text { досягнули }\end{array}$ & $\begin{array}{c}\text { лише } \\
71,43 \% \\
(\mathrm{n}=40) \\
\text { досягнули } \\
\end{array}$ & $\begin{array}{c}\text { лише } \\
80,85 \% \\
(\mathrm{n}=38) \\
\text { досягнули } \\
\end{array}$ & $\begin{array}{c}\text { лише } \\
84,78 \% \\
(\mathrm{n}=39) \\
\text { досягнули } \\
\end{array}$ \\
\hline $\begin{array}{l}\text { Вліво 25\% <Дельта } \\
\text { симетрії > Вправо 25\% }\end{array}$ & $\begin{array}{c}\text { лише } 32,98 \% \\
(\mathrm{n}=31) \\
\text { досягнули }\end{array}$ & $\begin{array}{c}\text { лише } 43,9 \% \\
(\mathrm{n}=36) \\
\text { досягнули }\end{array}$ & $\begin{array}{c}\text { лише } 52,7 \% \\
(\mathrm{n}=39) \\
\text { досягнули }\end{array}$ & $\begin{array}{c}\text { лише } \\
71,43 \% \\
(\mathrm{n}=40) \\
\text { досягнули }\end{array}$ & $\begin{array}{c}\text { лише } \\
74,47 \% \\
(\mathrm{n}=35) \\
\text { длсягнули }\end{array}$ & $\begin{array}{c}\text { лише } \\
76,09 \% \\
(\mathrm{n}=35) \\
\text { досягнули }\end{array}$ \\
\hline $\begin{array}{l}\text { Обертаючий момент > } \\
\pm 10 \text { Нм }\end{array}$ & $\begin{array}{l}\text { лише } 38,3 \% \\
(\mathrm{n}=36) \\
\text { досягнули }\end{array}$ & $\begin{array}{c}\text { лише 43,9\% } \\
(\mathrm{n}=36) \\
\text { досягнули }\end{array}$ & $\begin{array}{c}\text { лише } 55,41 \% \\
(\mathrm{n}=41) \\
\text { досягнули }\end{array}$ & $\begin{array}{c}\text { лише } \\
73,21 \% \\
(\mathrm{n}=41) \\
\text { досягнули }\end{array}$ & $\begin{array}{c}\text { лише } \\
87,23 \% \\
(\mathrm{n}=41) \\
\text { досягнули }\end{array}$ & $\begin{array}{c}\text { лише } \\
89,13 \% \\
(\mathrm{n}=41) \\
\text { досягнули }\end{array}$ \\
\hline
\end{tabular}

Пояснення використаних скорочень :

Сплутаність свідомості з аспонтанністю -6А-СПС з $A$

Мовнорухова сплутаність свідомості -6Б-МРCC

Амнестична сплутаність свідомості - $6 B-A C C$

Дисмнестичний синдром -7А-ДС

Корсаковський синдром - $7 Б-К C$

Синдром ясної свідомості - 8 -ЯС з КЕР

сокими рівнями свідомості, зі збереженим двостороннім вербальним контактом, відновленою побутовою активністю та загальною фізичною активністю в найближчому оточенні, при тому, що переважна кількість таких пацієнтів навіть могла пересуватися 3 незначною підтримкою, все ж зберігала значимі порушення ізольованого чи поєднаного функціонування кінцівок, порівняно з середньо груповими референтними значеннями (колонка "кінезіологічні показники" табл. 5). Під час тестування клінічно виразна латералізація змін м'язового тонусу чи глибини парезу в більшості досліджуваних випадків зміщувалася в меншу сторону за кінезіологічними показникам. Це вказує на приховані симптоми кінезіологічної дисфункції, 3 динамікою відновлення "тонких" кінезіологічних характеристик статусу пацієнта встановлено кореляційний прямий зв'язок $(\mathrm{r}<0,54)$ прогнозу переходу на вищу стадію посткоматозного порушення свідомості.

Таким чином, для комплексної оцінки ефективності реабілітаційного лікування пацієнтів з усвідомленою руховою активністю після тяжкої черепно-мозкової травми та з метою розробки індивідуальної програми

реабілітації доцільне залучення сучасних інструментальних (апаратних) методів кінезіологічного тестування поряд з визначенням загальних кінезіологічних показників.

\section{Висновки}

1.Використання кінезіотерапії в індивідуальних реабілітаційних програмах у пацієнтів після тяжкої черепно-мозкової травми призвело до приросту м'язової сили, фізичної активності та покращення загального стану, включаючи зростання інтелектуально-мнестичних процесів з реалізацією їх в найближчому оточенні.

2.Встановлено збереження порушень нейром'язевого контролю та властивостей реципрокної взаємодії згиначів та розгиначів усіх кінцівок при генерації максимальної роботи (максимальної сили) у рухових повторах чи актах, що мають циклічну характеристику, які на стадіях синдрому пригніченої свідомості тривалий час були паретичними (тетрапарез ВC, тетрапарез акінетичного мутизму).

3.Отримані кінезіологічні показники засвідчують про те, що реалізація поєднання координованості,

ISSN 1727-4338 https://ww.bsmu.edu.ua 
швидкості, темпу, фокусування (ціль-орієнтованість) руху, навіть на тлі відносно збереженої м'язової сили у таких хворих залишалася інтелектульно-мнестично залежною,

4.Клінічно прийнятні значення більшості досліджуваних показників у хворих з синдромом ясної свідомості майже в 2 рази частіше траплялися, а ніж у хворих з синдромом сплутаної свідомості з аспонтанністю $(\mathrm{p}<0,05)$.

\section{Перспективи подальших досліджень}

Оцінка ефективності реабілітаційного лікування за даними кінезіологічного обстеження пацієнтів 3 постравматичними посткоматозними розладами свідомості $\epsilon$ методом, що за інформативністю та значимістю відповідає клініко-неврологічному дослідженню та дає змогу визначити реабілітаційний прогноз. Для комплексної оцінки ефективності реабілітаційного лікування пацієнтів з усвідомленою руховою активністю після тяжкої черепно-мозкової травми та з метою розробки індивідуальної програми реабілітації доцільне залучення сучасних інструментальних (апаратних) методів кінезіологічного тестування поряд 3 визначенням загальних кінезіологічних показників.

\section{Список літератури}

1.Григорова IA, Куфтеріна НС. Динаміка когнітивних змін у хворих із наслідками закритої черепно-мозкової травми. Міжнародний неврологічний журнал. 2011;2:88-92.

2.Черненко II, Чухно IA. Епідеміологічні та клінічні аспекти наслідків черепно-мозкової травми. Вісник соціальної гігієни та організації охорони здоров'я України. 2017;4:5-11. doi: 10. 11603/1681-2786.2017.4.8646

3.Шевчук ВI, Кравченко ВВ, Беляєва НМ, Яворовенко ОБ. Особливості медико-соціальної експертизи та реабілітації інвалідів військової служби та учасників Антитерористичної операції: метод. реком. Вінниця; 2016. 43 с.

4.Archer T, Svensson K, Alricsson M. Physical exercise ameliorates deficits induced by traumatic brain injury. Acta Neurol Scand. 2012;125(5):293-302. doi: 10.1111/j.1600-0404.2011.01638.x

5.Brzuszkiewicz-Kuzmicka G, Kuzmicki S, Domaniecki J. Relationships between kinesiotherapy methods used in rehabilitation and the course of lost function recovery following surgical treatment of cranio-cerebral trauma. Brain Inj. 2012;26(12):14318. doi: $10.3109 / 02699052.2012 .694562$

6.Kreutzer JS, Stejskal TM, Ketchum JM, Marwitz JH, Taylor LA, Menzel JC. A preliminary investigation of the brain injury family intervention: impact on family members. Brain Inj. 2009; 23(6):535-47. doi: 10.1080/02699050902926291

7.7.Lendraitiene E, Petruseviciene D, Savickas R, Zemaitiene I, Mingaila S. The impact of physical therapy in patients with severe traumatic brain injury during acute and post-acute rehabilitation according to coma duration. J Phys Ther Sci. 2016; 28(7):2048-54. doi: 10.1589/jpts.28.2048

8. Wick JY. Traumatic brain injury: special problem, special care. Consult Pharm. 2012;27(6):392-9. doi: 10.4140/TCP. n.2012.392

9.Self M, Driver S, Stevens L, Warren AM. Physical activity experiences of individuals living with a traumatic brain injury: a qualitative research exploration. Adapt Phys Activ Q, 2013; 30(1):20-39.

10.de Guise E, Gosselin N, Leblanc J, et al. Clock drawing and mini-mental state examination in patients with traumatic brain injury. Appl Neuropsychol. 2011;18(3):179-90. doi: 10.1080/ 09084282.2011 .595444

11.Archer T. Influence of physical exercise on traumatic brain injury deficits: scaffolding effect. Neurotox Res. 2012;21(4):41834. doi: 10.1007/s12640-011-9297-0

12.Driver S, Ede A. Impact of physical activity on mood after ISSN 1727-4338 https://www.bsmu.edu.ua
TBI. Brain Inj. 2009;23(3):203-12. doi: 10.1080/026990508026 95574

13.Griffen JA, Hanks RA, Meachen S. The reliability and validity of the community integration measure in persons with traumatic brain injury. Rehabil Psychol. 2010;55(3):292-7. doi: $10.1037 / \mathrm{a} 0020503$

14.Крук Б, Рокошевська В, Білянський О. Фізична реабілітація осіб із черепно-мозковою травмою. Спортивна наука України [Інтернет]. 2015[цитовано 2019 Лют 27];1:66-9. Доступно: http://sportscience.ldufk.edu. ua/index.php/snu/article/view/292/285

15. Рибак ОЮ, Рибак ЛІ. Кінезіологія рухових якостей: метод. посіб. Львів; 2013. Частина 1; 44 с.

\section{References}

1.Grygorova IA, Kufterina NS. Dynamika kohnityvnykh zmin u khvorykh iz naslidkamy zakrytoi cherepno-mozkovoi travmy [Dynamics of cognitive changes in patients after closed craniocerebral injury]. International Neurological Journal. 2011; 2:88-92. (in Ukrainian).

2.Chernenko II, Chukhno IA. Epidemiolohichni ta klinichni aspekty naslidkiv cherepno-mozkovoi travmy [Epidemiological and clinical aspects of the craniocereberal trauma]. Bulletin of social hygiene and health protection organization of Ukraine. 2017;4:5-11. doi: 10.11603/1681-2786.2017.4.8646 (in Ukrainian).

3.Shevchuk VI, Kravchenko VV, Belyaieva NM, Yavorovenko OB. Osoblyvosti medyko-sotsial'noi ekspertyzy ta reabilitatsii invalidiv viis'kovoi sluzhby ta uchasnykiv Antyterorystychnoi operatsii [Features of medical and social examination and rehabilitation of disabled military service and participants of the Antiterrorist operation]: metod. rekom. Vinnytsia; 2016. 43 p. (in Ukrainian).

4.Archer T, Svensson K, Alricsson M. Physical exercise ameliorates deficits induced by traumatic brain injury. Acta Neurol Scand. 2012;125(5):293-302. doi: 10.1111/j.1600-0404.2011. 01638.x

5.Brzuszkiewicz-Kuzmicka G, Kuzmicki S, Domaniecki J. Relationships between kinesiotherapy methods used in rehabilitation and the course of lost function recovery following surgical treatment of cranio-cerebral trauma. Brain Inj. 2012;26(12):14318. doi: $10.3109 / 02699052.2012 .694562$

6.Kreutzer JS, Stejskal TM, Ketchum JM, Marwitz JH, Taylor LA, Menzel JC. A preliminary investigation of the brain injury family intervention: impact on family members. Brain Inj. 2009; 23(6):535-47. doi: 10.1080/02699050902926291

7.Lendraitiene E, Petruseviciene D, Savickas R, Zemaitiene I, Mingaila S. The impact of physical therapy in patients with severe traumatic brain injury during acute and post-acute rehabilitation according to coma duration. J Phys Ther Sci. 2016;28(7):2048-54. doi: $10.1589 /$ jpts. 28.2048

8.Wick JY. Traumatic brain injury: special problem, special care. Consult Pharm. 2012;27(6):392-9. doi: 10.4140/TCP.n. 2012.392

9.Self M, Driver S, Stevens L, Warren AM. Physical activity experiences of individuals living with a traumatic brain injury: a qualitative research exploration. Adapt Phys Activ Q, 2013; 30(1):20-39.

10.de Guise E, Gosselin N, Leblanc J, et al. Clock drawing and mini-mental state examination in patients with traumatic brain injury. Appl Neuropsychol. 2011;18(3):179-90. doi: 10.1080/ 09084282.2011 .595444

11.Archer T. Influence of physical exercise on traumatic brain injury deficits: scaffolding effect. Neurotox Res. 2012;21(4):41834. doi: $10.1007 / \mathrm{s} 12640-011-9297-0$

12.Driver S, Ede A. Impact of physical activity on mood after TBI. Brain Inj. 2009;23(3):203-12. doi: 10.1080/0269905080269 5574

13.Griffen JA, Hanks RA, Meachen S. The reliability and validity of the community integration measure in persons with traumatic brain injury. Rehabil Psychol. 2010;55(3):292-7. doi: $10.1037 / \mathrm{a} 0020503$

14.Kruk B, Rokoshevska V, Bilyansky O. Fizychna reabilitatsiia osib iz cherepno-mozkovoiu travmoiu [Physical rehabilitation persons with traumatic brain injury]. Sport Science of Ukraine [Internet]. 2015[tsytovano 2019 Liut 27];1:66-9. Dostupno:

Клінічна та експериментальна патологія. 2019. Т.18, №1 (67) 
http://sportscience.ldufk.edu.ua/index.php/snu/article/view/ 292/285 (in Ukrainian).

15.Rybak OYu, Rybak LI. Kineziolohiia rukhovykh yakostei
[Kinesiology of motor qualities]: metod. posib. L'viv; 2013. Chastyna 1; 44 p. (in Ukrainian).

\section{Відомості про авторів:}

Кулик О.В. - к.мед.н., докторант кафедри рефлексотерапії Харківської медичної академії післядипломної освіти м. Харків, Україна

\section{Сведения об авторах:}

Кулик А.В. - к.мед.н., докторант кафедры рефлексотерапии Харьковской медицинской академии последипломного образования г. Харьков, Украина

\section{Information about the authors:}

Kulyk A.V. - candidate of Medical Sciences, Department of Reflexotherapy, Kharkiv Medical Academy of Postgraduate Education, Kharkiv, Ukraine 